\title{
PENGARUH MODEL PEMBELAJARAN OPEN ENDED TERHADAP KEMAMPUAN BERPIKIR KRITIS SISWA KELAS V MATA PELAJARAN MATEMATIKA DI MI
}

\author{
${ }^{1)}$ Nurhaningtyas Agustin, Program Studi Pendidikan Guru Madrasah Ibtidaiyah, Institut Agama \\ Islam Nadhatul Ulama Tuban, email : nurhaning1992@gmail.com \\ ${ }^{2)}$ Lafifatun Ni'mah, Program Studi Pendidikan Guru Madrasah Ibtidaiyah, Institut Agama Islam \\ Nadhatul Ulama Tuban, email : lafifatun.nik@gmail.com
}

\begin{abstract}
Mathematics is one of the subjects that trains students to think critically, logically, analytically, systematically, and creatively. One of the regulations of the Minister of Nation Education No.23 of 2006 years, about "graduate competency standards" is to have the ability to cooperate. One way to develop students's critical thinking skills is to apply student oriented learning with open learning, Open Ended. The method in this study is an experimental method by applying an Open Ended learning model. The purpose of this study was to obtain data or information about the influence and general picture of students critical thinking skills after the application of Open Ended learning in teaching and learning in the classroom. In addition to get an overview of students respones to the application of Open Ended. This study took the population class V MI Al-Falahiyah Kedungrejo-Kerek-Tuban lesson years 2019/2020. This study uses the population as a score of data because the number of students studied is less than 100 students. Namely fifth grade students, amuting to 20 students. The instruments used as data collection were questionnaires and test of mathematical critical thinking skills in fraction subjects. The statistical test used was a t-test with a pre test and post test one group design. Students whos responded to learning with who Open Ended model with a score range's of 25-27by 10\%, a range scores of $28-30$ by 15\%, a range scores $31-33$ by 30\%, a range scores of 34-36 by $15 \%$, and 37-39 by 30\%. With 11 students who responded well, and 9 students who responded very good, to the Open Ended learning model. Hypothesis test results with the $t$-test thitung > t tabel $(2,109>2,029)$. While the average value of students mathematic critical thinking ability of students is categorized as moderate or sufficient.
\end{abstract}

Keywords: Open Ended Learning Model, Critical Thinking Skills, Mathematic.

\section{Pendahuluan}

Perkembangan teknologi dan informasi pada saat ini tidak dapat dipungkiri yang merupakan buah dari kemampuan berpikir kritis dan kreatif manusia. Manusia yang dibekali akal, budi, dan karsa menciptakan perubahan-perubahan terhadap pengetahuan yang ada dan mengimplementasikannya untuk memecahkan masalah-masalah yang dihadapi. Kemampuan berpikir kritis dan berpikir kreatif manusia juga didorong keinginan untuk hidup yang lebih baik 
dan sejahtera ditengah kondisi lingkungan yang semakin terbatas. ${ }^{1}$ Merujuk pada berbagai pendapat para ahli matematika Sekolah Dasar dalam mengembangkan berbagai kreativitas dan kompetensi siswa, maka guru hendaknya dapat menyajikan pembelajaran yang efektif dan efisien, sesuai dengan kurikulum dan pola pikir siswa. Dalam mengajarkan matematika, guru harus memahami bahwa kemampuan setiap siswa berbeda-beda, serta tidak semua siswa menyenangi pelajaran matematika. ${ }^{2}$

Pada salah satu tujuan kurikulum 2013 juga menekankan pada kreativitas dan tujuan kurikulum tersebut adalah "mengembangkan keseimbangan antara pengembangan sikap spiritual \& sosial, rasa ingin tahu, kreativitas, kerja sama dengan kemampuan intelektual dan psikomotorik". Dengan demikian semua bidang atau mata pelajaran termasuk matematika perlu mengembangkan model maupun strategi pembelajaran yang secara langsung atau tidak langsung yang dapat meningkatkan kemampuan berpikir kritis dan kreatif. Berpikir kritis dan kreatif jarang ditekankan pada pembelajaran matematika karena model pembelajaran yang diterapkan cenderung berorientasi pada pengembangan pemikiran analitis dengan masalah-masalah yang rutin. Menurut Beghetto dalam Siswono, bahwa para peneliti telah mengidentifikasi kendalakendala dalam pengembangan kreativitas (termasuk berpikir kritis) dikelas, yaitu: praktik pengajaran yang konvergen, sikap keyakinan guru terhadap kreativitas, motivasi lingkungan, dan keyakinan peserta didik sendiri terhadap kreativitas. ${ }^{3}$ Rendahnya kemampuan berpikir peserta didik berdampak pada rendahnya kecerdasan intelektual, dan hal ini merupakan tindakan yang harus segera diatasi oleh pendidik. Untuk mengatasi hal tersebut, banyak alternatif yang dapat dilakukan, beberapa diantaranya : guru sebagai tenaga pengajar dan pendidik harus selalu meningkatkan kualitas pengajaran dan pembelajaran di kelas. Selain itu, dalam meningkatkan kemampuan peserta didik perlu adanya media sebagai penyambung materi yang digunakan dengan hasil kemampuan yang harus dikuasai peserta didik. ${ }^{4}$ Atau dengan melibatkan siswa secara aktif dan efektif dalam proses belajar mengajar sesuai dengan penerapan kurikulum.

\footnotetext{
${ }^{1}$ Siswono, Tatag Yuli Eko. (2018). Pembelajaran Matematika Berbasis Pengajuan dan Pemecahan Masalah. Bandung: PT. Remaja Rosdakarya

${ }^{2}$ Heruman. (2007). Model Pembelajaran Matematika di Sekolah Dasar. Bandung: PT.Remaja Rosdakarya

${ }^{3} \operatorname{Ibid}(1)$

${ }^{4}$ Akhmad Aji Pradana, \& Jazilatul Ummah. (2020). PENGARUH MEDIA SEMPOA TERHADAP KEMAMPUAN OPERASI HITUNG PENGURANGAN SISWA KELAS II MI . PREMIERE : Journal of Islamic Elementary Education, 2(1), 94-102.
} 
Menurut Davis, model pembelajaran matematika yang khusus berorientasi pada upaya pengembangan berpikir kritis dan berpikir kreatif matematis jarang ditemukan. Guru disekolah lebih mengajarkan matematika secara hafalan dengan menggunakan masalah rutin. ${ }^{5}$ Menurut Huda, model pembelajaran yang lebih tepat untuk meningkatkan kemampuan berpikir siswa (kemampuan kritis dan kreatif), salah satunya dengan menerapkan model pembelajaran Open Ended. ${ }^{6}$ Pembelajaran terbuka atau yang sering dikenal dengan istilah Open Ended merupakan proses pembelajaran yang di dalamnya tujuan dan keinginan individu/siswa dibangun dan dicapai secara terbuka. Yaitu model pembelajaran yang menyajikan suatu permasalahan yang memiliki metode atau penyelesaian dengan benar yang lebih dari satu, sehingga dapat memberi kesempatan kepada siswa untuk memperoleh pengetahuan/pengalaman menemukan, menggali, dan memecahkan masalah dengan beberapa teknik. Jadi pembelajaran Open Ended lebih menekankan pada proses pencarian suatu jawaban bukan hanya mendapatkan jawaban semata. Melalui model pembelajaran Open Ended, siswa diharapkan aktif dalam belajar, aktif berdiskusi, berani menyampaikan gagasan dan menerima gagasan orang lain, kreatif dalam mencari solusi dari suatu permasalahan. Yang pada intinya tingkat kemampuan berpikir siswa menjadi lebih tinggi.

Bidang studi matematika yang diajarkan di SD mencakup tiga cabang, yaitu aritmetika, aljabar dan geometri. Aritmetika merupakan cabang matematika yang mencakup pengetahuan tentang bilangan, sedangkan aljabar berkenaan dengan penggunaan abjad dalam aritmatika, dan geometri berkenaan dengan titik dan garis. Dewasa ini, matematika tidak lagi dipandang sebagai ilmu, tetapi lebih daripada itu matematika digunakan sebagai sarana pencapaian tujuan hidup manusia dalam berbagai bidang. Pada bidang aritmetika terdapat materi bilangan (bilangan pecahan), yang mana pecahan mengalami perkembangan tertua di Mesir Kuno, bangsa Mesir mengenal pecahan berupa satuan (unit fraction). Pecahan sendiri merupakan sebuah istilah dalam matematika yang terdiri dari pembilang dan penyebut. Hakikat transaksi dalam bilangan pecahan adalah bagaimana cara menyederhanakan pembilang dan penyebut. Penyederhanaan pembilang dan penyebut akan memudahkan dalam operasi aritmetika sehingga tidak menghasilkan angka yang terlalu besar tetapi mempunyai nilai yang sama. Mempelajari bilangan pecahan sama

\footnotetext{
${ }^{5} \operatorname{Ibid}(1)$

${ }^{6}$ Huda, M. (2013). Model-Model Pengajaran dan Pembelajaran. Yogyakarta: Pustaka Pelajar
} 
halnya dengan belajar membagikan sesuatu dengan baik dan benar sesuai keinginan. Beberapa jenis bilangan pecahan yang harus dipelajari siswa, diantaranya: bilangan peahan murni, bilangan pecahan biasa, bilangan pecahan campuran, bilangan pecahan desimal, bilangan pecahan persen dan bilangan pecahan permil. Memberikan konsep dasar pecahan dikalangan anak Sekolah Dasar (SD), harus sesuai dengan logika mereka. Anak usia Sekolah Dasar memang kurang mampu memahami operasi logis dari konsep matematika tanpa bantuan alat peraga. Dengan bantuan alat peraga materi lebih mudah tersampaikan dan mudah diterima, dengan begitu siswa tidak akan membayangkan apa hakikatnya pecahan itu. Namun, untuk menumbuhkan kemampuan berpikir kritis pada siswa tidak hanya melalui alternatif benda-benda konkret yang dapat digunakan dalam pembelajaran bilangan pecahan. Disamping itu, guru harus memberikan pengajaran dan keterampilan-keterampilan khusus, beberapa prinsip-prinsip berpikir logis dan memberikan latihan-latihan dalam penyelesaian masalah dalam sebuah pembelajaran.

Berdasarkan hasil pra penelitian yang dilakukan peneliti dengan mewawancarai guru kelas V di MI Al-Falahiyah, bahwa keadaan peserta didik di MI Al-Falahiyah saat ini cenderung bergantung pada rumus-rumus yang tersedia dalam memecahkan masalah matematika, yang menjadi keprihatinan tersendiri bagi peneliti. Kebanyakan peserta didik saat ini cenderung bergantung pada penggunaan rumus-rumus matematika dalam memecahkan suatu masalah matematika. Ketika diberikan masalah matematika, siswa secara langsung akan merujuk pada rumus mana yang akan digunakan. Hal ini, mengakibatkan kurangnya kreatifitas dalam mencari solusi-solusi lain yang mungkin dalam penyelesaian masalah yang diberikan. Logika berpikir mereka menjadi kurang terarah karena "mindset" yang telah terbentuk yaitu menyelesaikan suatu masalah matematika hanya bisa dipecahkan atau diselesaikan dengan menggunakan rumus yang tepat dan hanya menggunakan satu cara penyelesaian masalah. Selain menganggap bahwa matematika adalah mata pelajaran yang sangat menyeramkan, peserta didik lebih suka menghindari matematika.

\section{Metode}

Penelitian ini menggunakan pendekatan kuantitatif dengan jenis penelitian eksperimen. Menurut Sugiyono, penelitian eksperimen adalah metode penelitian yang dilakukan dengan 
percobaan, yang merupakan metode kuantitatif, digunakan untuk mengetahui pengaruh variabel independen (tratment/perlakuan) terhadap variabel dependen (hasil) dalam kondisi yang terkendalikan. ${ }^{7}$ Penelitian ini dimaksudkan untuk meningkatkan kemampuan berpikir siswa kelas V MI Al-Falahiyah Kedungrejo-Kerek-Tuban. Khususnya kemampuan berpikir kritis melalui mata pelajaran matematika materi pecahan. Penelitian ini dilakukan dengan pretest proses pembelajaran ( $2 \mathrm{x}$ pertemuan) dan postest. Instrumen yang digunakan dalam penelitian ini adalah instrumen tes dan nontes. Instrumen tes berupa soal uraian pre test dan post test kemampuan berpikir kritis siswa, sedangkan instrumen nontes berupa angket respon siswa. Uji statistik yang digunakan adalah uji-t dengan desain pre test and post test one group.

\section{Hasil}

Hasil penelitian eksperimen ini diperoleh dari pelaksanaan pembelajaran di kelas dengan materi pecahan dan menggunakan model pembelajaran Open Ended yang dilakukan di kelas V MI Al-Falahiyah Kedungrejo-Kerek-Tuban, yang berlangsung selama 2x pertemuan, dengan alokasi waktu 2 x 35 menit/ pertemuan. Penelitian ini dilakukan dengan pemberian perlakuan/treatment yang dapat dihitung dengan cara membandingkan nilai pre test dan post test. Bila nilai post test lebih besar daripada pre test, maka perlakuan berlaku positif. Pre test tersebut diberikan guna untuk mengetahui keadaan awal siswa kelas $\mathrm{V}$, yaitu kondisi kemampuan berpikir kritis. Kemudian siswa diberi perlakuan yaitu penerapan model pembelajaran Open Ended. Dan setelah itu post test dilaksanakan guna untuk mendapatkan data atau informasi tentang keadaan siswa setelah mendapat perlakuan.

Berikut data hasil pre test dan post test siswa kelas V MI Al-Falahiyah tahun pelajaran 2019/2020.

Tabel 4.1

Data Hasil Pre Test dan Post Test

\begin{tabular}{|c|l|c|c|}
\hline No & \multicolumn{1}{|c|}{ Nama } & Pretest & Posttest \\
\hline 1 & Betania Eden & 60 & 73 \\
\hline 2 & Doni Renaldi & 47 & 40 \\
\hline 3 & Dwi Marsya & 60 & 73 \\
\hline
\end{tabular}

\footnotetext{
${ }^{7}$ Sugiyono. (2019). Metode Penelitian Kuantitatif, Kualitatif dan R\&D. Bandung: Alfabeta.
} 


\begin{tabular}{|c|l|c|c|}
4 & Erna Ningsih & 80 & 87 \\
\hline 5 & Faizatul Ulya & 80 & 87 \\
\hline 6 & Hernita & 73 & 80 \\
\hline 7 & Khoirul Rokib & 47 & 33 \\
\hline 8 & Labiqul Khoiri & 60 & 80 \\
\hline 9 & Linda Sri Astuti & 73 & 80 \\
\hline 10 & Malihatul Husna & 67 & 67 \\
\hline 11 & Muh. Afifuddin & 80 & 80 \\
\hline 12 & Muh. Syafi'i & 60 & 67 \\
\hline 13 & Muh. Syifa'ul & 80 & 87 \\
\hline 14 & Nanang Febri & 67 & 73 \\
\hline 15 & Nur Lailatul & 87 & 87 \\
\hline 16 & Pupung Sayoga & 53 & 53 \\
\hline 17 & Qodirun & 80 & 87 \\
\hline 18 & Suahmadi & 53 & 60 \\
\hline 19 & Wafiqian & 73 & 67 \\
\hline 20 & Yuliana & 53 & 47 \\
\hline
\end{tabular}

Kemudian nilai pre test siswa dianalisis dan disajikan dalam sebuah tabel distribusi frekuensi. Berikut tabel distribusi frekuensi nilai pre test.

Tabel 4.2

Distribusi Frekuensi Nilai Pre Test

\begin{tabular}{|c|c|c|c|c|c|c|c|c|}
\hline Nilai & $f_{i}$ & $x_{i}$ & $f_{i} \cdot x_{i}$ & $\bar{x}$ & $x_{i}-\bar{x}$ & $\left(x_{i}-\bar{x}\right)^{2}$ & $f_{i}\left(x_{i}-\bar{x}\right)^{2}$ & $\%$ \\
\hline $47-54$ & 5 & 50,5 & 252,5 & \multirow{6}{*}{66,9} & $-16,4$ & 268,96 & 1344,8 & 25 \\
\hline $55-62$ & 4 & 58,5 & 234 & & $-8,4$ & 70,56 & 282,24 & 20 \\
\hline $63-70$ & 2 & 66,5 & 133 & & $-0,4$ & 0,16 & 0,32 & 10 \\
\hline $71-78$ & 3 & 74,5 & 223,5 & & 7,6 & 57,76 & 173,28 & 15 \\
\hline $79-87$ & 6 & 82,5 & 495 & & 15,6 & 243,36 & 1460,16 & 30 \\
\hline$\sum$ & 20 & 332,5 & 1338 & & -2 & 640,8 & 3260,8 & 100 \\
\hline
\end{tabular}


Berdasarkan tabel 4.2 nilai pre test siswa kelas V MI Al-Falahiyah pada pembelajaran matematika, yang bertujuan untuk mengukur kemampuan berpikir kritis siswa memperoleh nilai rata-rata 66,9 dengan standar deviasi (SD) 12,769 (dibulatkan 13). Selanjutnya peneliti menyajikan data post test dalam bentuk tabel distribusi frekuensi. Berikut tabel distribusi frekuensi:

\section{Tabel 4.3}

Distribusi Frekuensi Nilai Post Test

\begin{tabular}{|c|c|c|c|c|c|c|c|c|}
\hline Nilai & $f_{i}$ & $x_{i}$ & $f_{i} \cdot x_{i}$ & $\bar{x}$ & $x_{i}-\bar{x}$ & $\left(x_{i}-\bar{x}\right)^{2}$ & $f_{i}\left(x_{i}-\bar{x}\right)^{2}$ & $\%$ \\
\hline $33-43$ & 2 & 38 & 76 & \multirow{6}{*}{69,9} & $-31,9$ & 1017,61 & 2035,22 & 10 \\
\hline $44-54$ & 2 & 49 & 98 & & $-20,9$ & 436,81 & 873,62 & 10 \\
\hline $55-65$ & 1 & 60 & 60 & & $-9,9$ & 98,01 & 98,01 & 5 \\
\hline $66-76$ & 6 & 71 & 426 & & 1,1 & 1,21 & 7,26 & 30 \\
\hline $77-87$ & 9 & 82 & 738 & & 12,1 & 146,41 & 1317,69 & 45 \\
\hline$\sum$ & 20 & 300 & 1398 & & $-49,5$ & 1700,05 & 4331,8 & 100 \\
\hline
\end{tabular}

Berdasarkan tabel 4.3 nilai post test siswa kelas V MI Al-Falahiyah pada pembelajaran matematika dengan penerapan model pembelajaran Open Ended, yang bertujuan untuk mengukur kemampuan berpikir kritis siswa memperoleh nilai rata-rata 69,9 dengan standar deviasi (SD) 14,717 (dibulatkan 15). Ternyata hasil pre test dan post test ada peningkatan pada nilai rata-rata. Untuk nilai statistik disajikan pada tabel berikut ini:

Tabel 4.4

Data Statistik Nilai Pre Test dan Post Test

\begin{tabular}{|l|c|c|}
\hline \multirow{2}{*}{\multicolumn{1}{|c|}{ Statistik }} & \multicolumn{2}{c|}{ Nilai Statistik } \\
\cline { 2 - 3 } & Pre Test & Post Test \\
\hline Nilai Tertinggi & 87 & 87 \\
\hline Nilai Terendah & 47 & 33 \\
\hline Nilai Rata-rata & 66,9 & 69,9 \\
\hline Varians & 163,04 & 216,59 \\
\hline Standar Deviasi & 12,76871 & 14,717 \\
\hline
\end{tabular}


Jika hasil tes siswa dikelompokkan dalam kategori rendah, sedang, tinggi, akan diperoleh frekuensi dan persentase setelah dilakukan pre test dan post test. Maka dari itu, kemampuan berpikir kritis siswa dikategorikan sedang atau cukup.

Tabel 4.5

Tingkat Kategori Kemampuan Berpikir Kritis

\begin{tabular}{|c|c|c|c|c|c|}
\hline $\begin{array}{c}\text { Kemampuan } \\
\text { Berpikir } \\
\text { Kritis }\end{array}$ & \multirow{2}{*}{ Kategori } & \multicolumn{2}{|c|}{ Pre Test } & \multicolumn{2}{c|}{ Post Test } \\
\cline { 3 - 6 } & & Frekuensi & Persentase & Frekuensi & persentase \\
\hline $0-55$ & Rendah & 5 & $25 \%$ & 4 & $20 \%$ \\
\hline $56-75$ & Sedang & 9 & $45 \%$ & 7 & $35 \%$ \\
\hline $76-100$ & Tinggi & 6 & $30 \%$ & 9 & $45 \%$ \\
\hline Jumlah & & 20 & $100 \%$ & 20 & $100 \%$ \\
\hline
\end{tabular}

Berdasarkan tabel 4.5 dapat diketahui bahwa pada pre test ada 5 siswa yang berada pada kategori rendah, dan 9 siswa pada kategori sedang dan 6 siswa pada kategori tingkat tinggi. Dan pada post test terdapat 4 siswa termasuk dalam kategori siswa berkemampuan pikir kritis rendah, dan 7 siswa berkemampuan pikir kritis sedang dan 9 siswa berkemampuan pikir kritis tinggi. Selanjutnya peneliti menyajikan data pre test dan post test dalam bentuk diagram. Berikut diagram perbandingan kategori siswa berkemampuan pikir kritis pada mata pelajaran matematika melalui pre test dan post test.

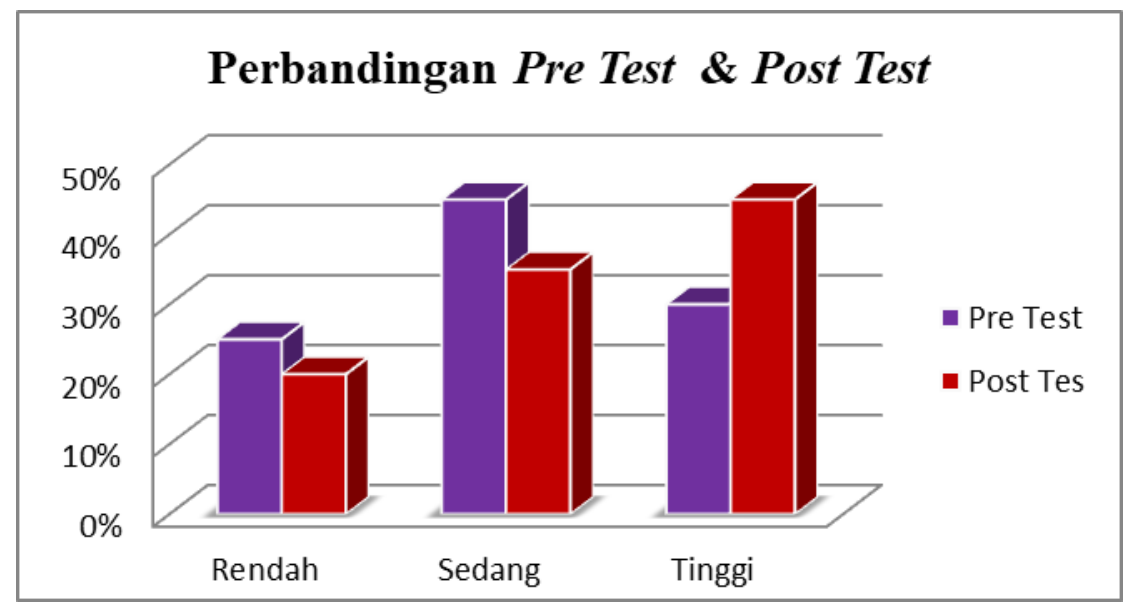

Gambar 4.1 Diagram Perbandingan Kategori Siswa Kemampuan Berpikir Kritis 
Dari gambar 4.1 perbandingan kategori siswa berkemampuan pikir kritis mengalami peningkatan pada post test di kemampuan berpikir kritis kategori tinggi. Pada kategori rendah mengalami penurunan yaitu pada pre test terdapat $25 \%$ siswa, dan post test menjadi $10 \%$ siswa, kemudian untuk kategori sedang mengalami penurunan lagi yaitu: pada pre test terdapat $45 \%$ siswa, sedangkan untuk post test terdapat 35\% siswa. Kemudian pada kategori tingkat tinggi mengalami kenaikan $15 \%$, pada nilai pre test terdapat $30 \%$ siswa sedangkan untuk post test terdapat $45 \%$ siswa.

Untuk mengetahui respon siswa terhadap model pembelajaran Open Ended yang telah dilakukan selama 2 kali pertemuan digunakan lembar angket respon siswa yang diberikan setelah siswa mengerjakan soal post test. Analisis respon siswa pada kelas eksperimen diperoleh presentase pada distribusi frekuensi dibawah ini:

\section{Tabel 4.6}

Hasil Analisis Angket Respon Siswa Terhadap Model Pembelajaran Open Ended.

\begin{tabular}{|c|c|c|c|c|}
\hline Skor & $f_{i}$ & $x_{i}$ & $f_{i . x_{i}}$ & Persentase \\
\hline $25-27$ & 2 & 26 & 52 & $10 \%$ \\
\hline $28-30$ & 3 & 29 & 87 & $15 \%$ \\
\hline $31-33$ & 6 & 32 & 192 & $30 \%$ \\
\hline $34-36$ & 3 & 35 & 105 & $15 \%$ \\
\hline $37-39$ & 6 & 36 & 216 & $30 \%$ \\
\hline Jumlah & 20 & 158 & 652 & $100 \%$ \\
\hline
\end{tabular}

Berdasarkan tabel 4.6 siswa yang merespon pembelajaran dengan model Open Ended dengan rentang skor 25-27 sebanyak 10\%, rentang skor 28-30 sebanyak 15\%, rentang skor 31-33 sebanyak 30\%, rentang skor 34-36 sebanyak 15\% dan 37-39 sebanyak 30\%. Kemudian hasil tersebut akan dikategorikan menjadi 3 kategori yaitu: (1) sangat baik, (2) baik, (3) cukup, (4) kurang, dan (5) sangat kurang. Untuk mengkategorikan respon siswa, peneliti menggunakan rumus manual dengan mengurangkan nilai tertinggi dengan niai terendah lalu dibagi dengan jumlah kriteria yang ditentukan. Berikut tabel kategori respon angket siswa terhadap pembelajaran Open Ended dalam pembelajaran matematika. 
Tabel 4.7

Tingkat Kategori Respon Siswa Terhadap Pembelajaran Open Ended

\begin{tabular}{|c|c|c|c|}
\hline $\begin{array}{c}\text { Skor } \\
\text { Respon } \\
\text { Siswa }\end{array}$ & Frekuensi & Kategori & Persentase \\
\hline $0-8$ & & & \\
\hline $9-16$ & 0 & Sangat Kurang & $0 \%$ \\
\hline $17-24$ & 0 & Kurang & $0 \%$ \\
\hline $25-32$ & 11 & Cukup & $0 \%$ \\
\hline $33-40$ & 9 & Baik & $55 \%$ \\
\hline
\end{tabular}

Berdasarkan tabel 4.7 Ditunjukkan siswa yang merespon sangat kurang baik tidak ada, respon kurang juga tidak ada tidak ada pula yang merespon dengan kategori cukup, dan yang merespon baik ada 11 siswa dan terdapat 9 siswa merespon pembelajaran Open Ended dengan sangat baik. Kemudian peneliti menyajikan analisis data tersebut dalam bentuk diagram. Berikut diagram persentase respon siswa pada pembelajaran Open Ended:

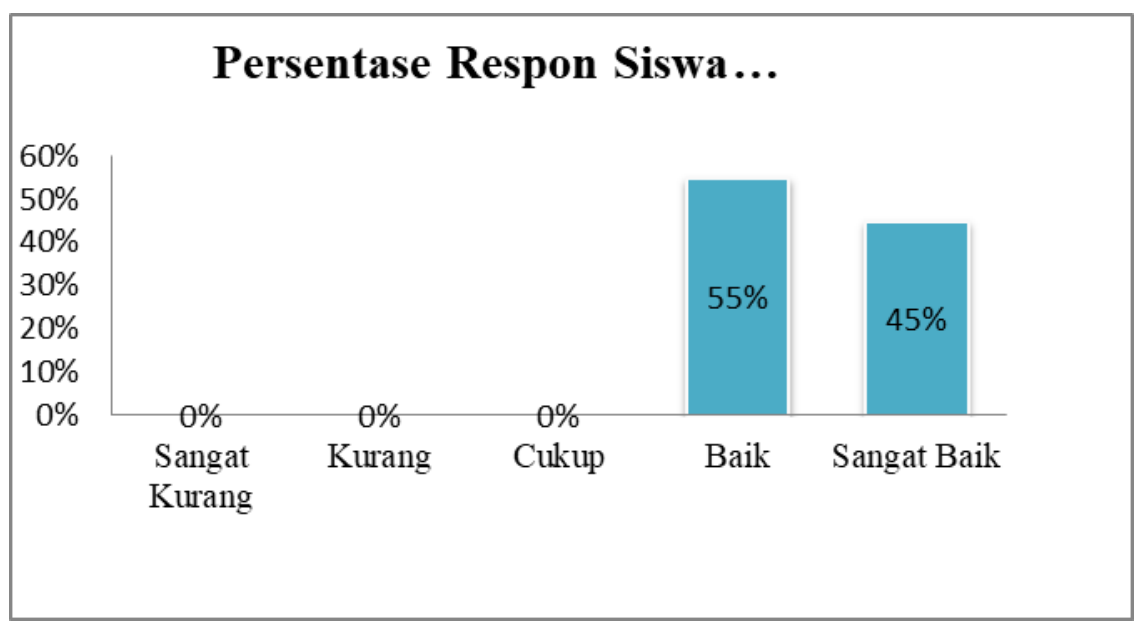

Gambar 4.2 Persentase Angket Respon Siswa

Berdasarkan gambar 4.2 terdapat 55\% siswa yang merespon pembelajaran Open Ended pada mata pelajaran matematika dengan baik, 45\% siswa merespon dengan sangat baik. Jadi, 
penerapan model pembelajaran Open Ended dalam mata pelajaran matematika di MI AlFalahiyah rata-rata direspon dengan baik oleh siswa kelas V.

Adapun dalam pengujian hipotesis penelitian eksperimen peneliti menggunakan teknik statistik dengan menggunakan uji $\mathrm{t}$ jenis pre test and post test one group design. Berikut tabel hasil analisis uji t pre test and post test one group design:

\section{Tabel 4.8}

Hasil Analisis Gain Score

\begin{tabular}{|c|l|c|c|c|c|c|}
\hline No & \multicolumn{1}{|c|}{ Nama } & $\begin{array}{c}\text { Pre } \\
\text { Test }\end{array}$ & $\begin{array}{c}\text { Post } \\
\text { Test }\end{array}$ & $\begin{array}{c}\text { Gain } \\
\text { Score }\end{array}$ & $X_{d}$ & $x_{d}{ }^{2}$ \\
\hline 1 & Betania E & 60 & 73 & 13 & 9,25 & 85,5625 \\
\hline 2 & Doni R & 47 & 40 & -7 & $-10,75$ & 115,5625 \\
\hline 3 & Dwi M & 60 & 73 & 13 & 9,25 & 85,5625 \\
\hline 4 & Erna N & 80 & 87 & 7 & 3,25 & 10,5625 \\
\hline 5 & Faizatul U & 80 & 87 & 7 & 3,25 & 10,5625 \\
\hline 6 & Hernita & 73 & 80 & 7 & 3,25 & 10,5625 \\
\hline 7 & Khoirul R & 47 & 33 & -14 & $-17,75$ & 315,0625 \\
\hline 8 & Labiqul K & 60 & 80 & 20 & 16,25 & 264,0625 \\
\hline 9 & Linda S & 73 & 80 & 7 & 3,25 & 10,5625 \\
\hline 10 & Malihatul H & 67 & 67 & 0 & $-3,75$ & 14,0625 \\
\hline 11 & Muh. Afif & 80 & 80 & 0 & $-3,75$ & 14,0625 \\
\hline 12 & Muh. Syafi'i & 60 & 67 & 7 & 3,25 & 10,5625 \\
\hline 13 & Muh. Syifa'ul & 80 & 87 & 7 & 3,25 & 10,5625 \\
\hline 14 & Nanang F & 67 & 73 & 6 & 2,25 & 5,0625 \\
\hline 15 & Nur Lailatul & 87 & 87 & 0 & $-3,75$ & 14,0625 \\
\hline 16 & Pupung S & 53 & 53 & 0 & $-3,75$ & 14,0625 \\
\hline 17 & Qodirun & 80 & 87 & 7 & 3,25 & 10,5625 \\
\hline 18 & Suahmadi & 53 & 60 & 7 & 3,25 & 10,5625 \\
\hline 19 & Wafiqian & 73 & 67 & -6 & $-9,75$ & 95,0625 \\
\hline 20 & Yuliana & 53 & 47 & -6 & $-9,75$ & 95,0625 \\
\hline & Jumlah & 1333 & 1408 & 75 & 0 & 1201,75 \\
\hline
\end{tabular}

Dari tabel 4.8 dapat diketahui Gain Score $\left(\sum \mathrm{d}\right) 75, \sum \mathrm{xd}^{2}=1201,75$ dengan $\mathrm{N}=20$. Kemudian hasil perhitungan dibandingkan harga $t$ tabel dengan $\mathrm{df}=\mathrm{N}-1$ pada taraf signifikansi $5 \%$ dengan hasil sebagai berikut:

$$
\mathrm{t} \text { hitung } \quad=2,108705839 / \mathrm{t} \text { hitung }=2,109
$$


$\mathrm{t}$ tabel $\quad=1,7291 / \mathrm{t}$ hitung $=2,029$

$\mathrm{t}$ hitung $>\mathrm{t}$ tabel $=2,109>2,029$

Dari uraian diatas dapat diketahui bahwa dengan taraf signifikansi 5\% t hitung $>\mathrm{t}$ tabel dengan arti hipotesis nihil (Ho) ditolak, sedangkan hipotesis alternatif (Ha) diterima. Jadi, ada pengaruh model pembelajaran Open Ended terhadap kemampuan berpikir siswa kelas V pada mata pelajaran matematika di MI Al-Falahiyah Kedungrejo-Kerek tahun pelajaran 2019/2020.

Berdasarkan analisis data, aspek dalam setiap sintaks telah banyak terlaksana. Hal ini menandakan bahwa kemampuan guru dalam mengelola kelas meningkat, yang akhirnya berdampak positif terhadap kemampuan berpikir siswa prestasi yang dapat ditunjukkan dengan meningkatnya nilai rata-rata dari pre test ke post test. Guru sebagai mediator dan fasilitator juga sangat mengoptimalisasi perannya. Hal ini dapat diartikan, bahwa penerapan model pembelajaran Open Ended pada mata pelajaran matematika materi pokok pecahan pada siswa kelas V MI Al-Falahiyah Kedungrejo-Kerek-Tuban tahun pelajaran 2019/2020 berpengaruh positif.

Model belajar Open Ended ini efektif digunakan dalam pembelajaran matematika karena mampu mengembangkan kemampuan berpikir kritis siswa dan memotivasi siswa serta meningkatkan keterlibatan siswa dalam proses penyelesaian suatu masalah. Siswa terlihat lebih aktif dan bersemangat dalam proses pembelajaran.

Guru sebagai pembimbing dan motivator untuk siswa menemukan konsep penyelesaian masalah, sehingga ingatan akan materi tersebut kuat karena didapat dari pengalaman dan kemampuannya dalam berpikir sehingga berimbas pada peningkatan berpikir kritis siswa tersebut. Selain itu, hal ini dapat mengurangi tingkat kejenuhan siswa dalam belajar, sehingga siswa tetap memiliki motivasi yang tinggi untuk belajar.

\section{Kesimpulan}

Kemampuan berpikir kritis siswa kelas V MI Al-Falahiyah dapat diketahui oleh penulis dengan melaksanakan pre test. Pre test ini untuk mengetahui keadaan awal siswa sebelum mendapat perlakuan, perlakuan pada penelitian ini berupa model pembelajaran Open Ended. Hasil penelitian peneliti melalui pre test yang diadakan oleh peneliti ternyata ada $25 \%$ dari 20 jumlah siswa berkemampuan pikir kritis kategori rendah, dan $45 \%$ berkemampuan pikir kritis 
sedang dan 30\% berkemampuan pikir kritis tinggi. Jadi, mayoritas siswa kelas V MI AlFalahiyah Kedungrejo-Kerek-Tuban memiliki kemampuan berpikir kritis kategori sedang. Kategori sedang ini sebelum adanya perlakuan penerapan model pembelajaran Open Ended. Jadi, keadaan kemampuan berpikir kritis awal siswa adalah sedang.

Pembelajaran Open Ended di MI Al-Falahiyah berlangsung dengan lancar. Berdasarkan hasil penelitian yang telah dilakukan oleh peneliti, diperoleh suatu kesimpulan umum antara lain bahwa tujuan pembelajaran tingkat tinggi dimungkinkan untuk dikembangkan melalui pembelajaran Open Ended. Hasil penelitian menunjukkan bahwa respon siswa kelas V pada model pembelajaran Open Ended, melalui pembelajaran matematika terdapat 55\% siswa yang merespon pembelajaran Open Ended pada mata pelajaran matematika dengan baik, 45\% siswa merespon dengan sangat baik. Jadi, penerapan model pembelajaran Open Ended dalam mata pelajaran matematika di MI Al-Falahiyah rata-rata direspon dengan baik oleh siswa kelas V.

Pengaruh model pembelajaran Open Ended terhadap mata pelajaran matematika kelas V di MI Al-Falahiyah, didapatkan data dari instrumen jenis non tes (lembar tes) pre test dan post test. Yang kemudian dianalisis menggunakan uji t, yang menunjukkan besarnya hasil perhitungan/t hitung dibandingkan harga t tabel dengan $\mathrm{df}=\mathrm{N}-1$ pada taraf signifikansi $5 \%$ dengan hasil $\mathrm{t}$ hitung $>\mathrm{t}$ tabel $=2,109>2,029$. Dari sini dapat diketahui bahwa dengan taraf signifikansi 5\% t hitung $>\mathrm{t}$ tabel dengan arti hipotesis nihil (Ho) ditolak, sedangkan hipotesis alternatif (Ha) diterima. pengaruh antara variabel model pembelajaran Open Ended sebagai variabel bebas dan kemampuan berpikir siswa dalam pembelajaran matematika sebagai variabel terikat secara serentak menunjukkan adanya pengaruh. Hal ini memperlihatkan bahwa variabel model pembelajaran Open Ended berpengaruh terhadap kemampuan berpikir siswa dalam mata pelajaran matematika. Sebagaimana telah kita ketahui bersama bahwa setiap kegiatan akan berpengaruh terhadap tingkah laku ataupun perbuatan sesuatu. Jadi, ada pengaruh model pembelajaran Open Ended terhadap kemampuan berpikir siswa kelas V pada mata pelajaran matematika di MI Al-Falahiyah Kedungrejo-Kerek tahun pelajaran 2019/2020.

\section{Daftar Referensi}

Heruman. (2007). Model Pembelajaran Matematika di Sekolah Dasar. Bandung: PT.Remaja Rosdakarya 
Huda, M. (2013). Model-Model Pengajaran dan Pembelajaran. Yogyakarta: Pustaka Pelajar Pradana, Akhmad Aji \& Jazilatul Ummah. (2020). PENGARUH MEDIA SEMPOA TERHADAP KEMAMPUAN OPERASI HITUNG PENGURANGAN SISWA KELAS

II MI . PREMIERE : Journal of Islamic Elementary Education, 2(1), 94-102.

Siswono, Tatag Yuli Eko. (2018). Pembelajaran Matematika Berbasis Pengajuan dan Sugiyono. (2019). Metode Penelitian Kuantitatif, Kualitatif dan R\&D. Bandung: Alfabeta. 